\title{
Images and Motives of the Italian Text in the Russian Literature of XIX-XX CC
}

\author{
Anastasia Kondrasheva
}

Rome University La Sapienza

anastasia.kondrasheva@uniroma1.it

Doi:10.5901/ajis.2013.v2n3p431

\begin{abstract}
This article highlighted the complex images and motives of the «Italian text» in the Russian literature of the XIX-XX centuries . "Italy" is seen not so much as an indication of a kind of historical and geographical realities, but above all it is as a sign of special art space containing in itself a number of categories of non-spatial attributes, along with the territorial and geographical features (aesthetic, religious, ethical or political ) .
\end{abstract}

Keywords : "Italian text " of the Russian literature , image, motive , myth.

Many Russian poets and writers dedicated to Italy their best works with a great inspiration. Everyone who has visited this country with its amazing cities like open-air museums, with breathtaking scenery and a masterpiece of art. At various times they lived there and traveled, often settling permanently in this " Promised Land ."

The emergence of the Italian theme in Russian literature associated with the expansion of the poetic "geography" of the artistic creativity and the desire of the Russian writers to comprehend the place of their country in the European cultural space. The study of this literary phenomenon (which has a long tradition) today acquired a new meaning in the context of the processes that take place in the spiritual, social and political life of the modern society. Russian scientists consider one of the most pressing problems of the late XX - early XXI century, the problem of the interaction between Russia and Europe, as the recent controversy about the extent whether Russia belongs to Europe and what it means for Russia. «The problem of the European cultural identity" remind of the discussions of the XIX century and the beginning of the debate XX centuries. Again the questions raised about the Slavophilism and Westernism, mutual attractions and repulsions of the cultures of Russia and the West, about the nature and role of the Russian European, as in the context of these issues will be finally resolved the problem of the the cultural and political destiny of Russia in the XXI century.

Every Russian writer saw Italy in his own way, depending on the time and on his own preferences. At the beginning of the last century, Valeriy Bryusov was looking for the majestic shadows of the past, live antiquity in this country. As Bryusov reported from Italy: "The whole ancient world - as alive - - The Forum, the Palatine, the baths of Caracalla , the Appian road , two Capitoline Museums ... choked the old days "[Bryusov, 1996]

Ivan Bunin was literally drunk from the sea air canals of Venice, the flavors of Capri. In "The Gentleman from San Francisco " a keen artist and stylist then managed to uncover all the aspects of life in Italy - its manners, customs, nature and its peculiar people.

In a different way Italy was presented by the Russian writer Maxim Gorky. He lived a long time in this country, loved its people - fishermen, farmers, artisans, workers and their children. Being in Rome he wrote "I think that I had absorbed a wave of spiritual health, energy, faith in life, because of the human spirit rose, everything boils in my heart , I feel strong, energetic, capable of many things ". [«Soviet writers about Italy», 1986]

The appeal of the images of Italy became the " life program " of a number of Russian writers such as V.Zhukovsky , K. Batiushkov, E.Baratynsky, N. Gogol, F.Dostoevsky, N.Nekrasov, A. Fet, I.Turgenev, F.Tyutchev, A.Maykov, A. Grigoriev, I.Aksakova, P.Vyazemsky, in the XX century - V.Brusov, A. Akhmatova, N.Gumilev, K. Balmont , S.Gorodetsky, A. Blok, A.Beliy, Viacheslav Ivanov, J. Brodsky, A.Kushner, E.Reyn, G. Sapgir and many others.

The image of Italy as reflected in letters and travel notes, and in works of art, becoming not only the scene of many of them, but also a way of expressing a special attitude. In this regard, in order not to talk about individual Italian impressions of a writer , you can refer to the concept of " the Italian text " of the Russian literature as a special kind of meaningful form, inseparable , "... the myth and the whole sphere of the symbolic " defined the unity and integrity "maximum semantic unit ( ideas ) . " [Toporov, 1995] 
The criteria for selection of the "italian text ", which is defined as "... the entire text set of the Russian poetry , thematically related to the cultural representation of Italy ", and is voiced in the Italian explorer Russian literature. [Garzonio, 2001] "On the one hand, - the scientist says - it is there is a lot of materials after Peter the Great' rich tradition of translations, imitations, adaptations of the Italian poetic texts , and on the other, the entire set of poetic texts devoted to Italy and Italian themes can be defined as the" italian experience ". [Garzonio, 2001]

The list of works devoted to Russian - Italian literary relations is quite extensive . First of all you need to call a number of studies related to the common problem of formation in the Russian literature of the XIX century, the concepts of "the West " - " East", " Russia and the West " , and secondly, the work related to the study of direct Russian -Italian contacts in the various areas of the cultural life - literature, painting, architecture, music, and thirdly, the work conceptually highlighting the problems in the functioning of local Russian literature, in relation to the " Italian " word - " roman ", " venetian ", to a lesser extent, " florentine " and fourthly , a number of individual studies devoted to travel, as Russian artists, poets and writers of the XVIII-XX centuries in Italy, and their Italian experience, as reflected in the letters , diaries, and literary texts. In addition, a special place is occupied by works of Russian writers bonds XVIII-XX centuries, the literary heritage of the iconic Russian consciousness poets - Dante, Petrarch , Ariosto , which determined the richness of many components of the "italian myth" of Russian literature. [Konstantinova, 2005]

Thus, this article will try to highlight the complex of the images and motives of the " Italian text " in Russian literature of the XIX-XX centuries .

As it was already noted , the place name "Italy" is seen not so much as an indication of the kind of historical and geographical reality but first of all as a sign of special art space containing in itself, along with the territorial and geographical features of a number of categories of non-spatial attributes ( aesthetic, religious, ethical or political). The myth of Italy is fully and adequately reflected in the single "italian text " of Russian literature as a phenomenon that exists in a kind of "collective consciousness".

In literature « Italian text» contains the whole paradigm of the common places - the subject and the language formulas, narrative and syntactic constructions that define , in turn , a special extraempiric meaning of " the Italian text", its sacred mythological level. [Konstantinova, 2005] There are numerous poems about Italy by V.K.Kyuhelbeker , A.Pushkin, E.Baratynskiy, P. Vyazemsky, M.Voloshin, V.Brusov, A. Akhmatova , N.Gumilev, C.Gorodetskiy , K. Balmont, A. Block, A.Beliy , Sasha Cherny, V.Ivanov , B.Zaytseva, Brodsky , A. Kushner , E. Reina , G. Sapgir and many others.

Italy - " a luxury country" - is presented as a separate world, unearthly, opposed to the northern world ( "snow country "), the world of "cold fuss ." This space is correlated with the Paradise (" It's all a paradise ..."), with a " brilliant garden ", «...где в облаке мечтаний / Еще живут Рафраэль и Торкват!» [Vjazemsky, 1986]

The topic of the " italian text " according to S.Konstantinova consists of , on the one hand, the conventional landscape, including "eternally blue sky", " the eternal laurel and cyp [ress ", where each element of the landscape becomes a kind of marker " Italian text ". 10] On the other hand, the quite clearly fixed range of cultural images related to the history and art of Italy: an indispensable sounding «Tass octave» and " breath of flame feelings" in the paintings of Raphael and Titian. In Russian poetry of the first half of the XIX century the complex of "Italian" images often becomes the core of the text , such as a P. Vyazemsky letter «K итальянцу, возвращающемуся в отечество» (1816). The first strophe is a typical and recognizable Italian landscape:

«Под небо голубым Италии прекрасной,

В отечестве надежд и счастья сладких снов,

Где воздух напоен любовью сладострастной,

Где мирт колеблется и блеск златых плодов...» [Vjazemsky, 1986]

The concept of the "Italian text " as the essential phenomenon isn't introduced in this case, similar to the " petersburg text " proposed in several papers by V.Toporov . According to Toporov the integral unity of this kind of text "... creates such a strong energy field that all the " set- different ", " colorful ", individual and appraisal of things involved in this field , captured it, and how it would be transubstantiated into the flesh and the spirit of a single text "[Toporov, 1995].

Also Konstantinova notes the dream motive as the common feature of the most poems about Italy, creating a sense of an unreachable distant, mysterious country ( Kiichelbecker : " Уже волшебница мечта / Рисует мне обитель славы..." ( Прощаниеl" ) ; Venevitinov : " Без горя я с мечтами распрощаюсь...» («Италия»). This motif shall receive the following - the motif of unbridled desire to Italy ( Kiichelbecker : " To you I spread my palms ... " (" Farewell "). Later in the text under consideration arises tune of " Wonderland " ( Kiichelbecker : "I was in a wonderful country "; Venevitov "And in reality , the circle of your miracles ..."(«Италия»). 
This motive is also directly connected to the motive of the gloss and shine, showing up as a poem Venevitinov, and in the lyrics Kyuchelbeker ( Venevitinov : " «Был я в стране чудесной» " (" Прощание ").

According to the previous motives connected to the desire for Paradise and immortality bound we can mention the next stable component of the " the Italian text " - the appearance of ghosts - ( Venevitinov : «Я буду жить в минувшем средь певцов, / Я вызову их тени из гробов!») («Италия»).

The integrity of the "italian text » of the XIX century is stipulated first of all due to its semantic orientation, creating a special kind of semantic field, developing the values of the author . Italy is perceived as romantic "the world of true being , "the world of abstract temporality , historicity and life limitations. Secondly, the design of the artistic model of the « italian text» comes at the expense of a special kind of imagery, recognizable landmarks, markers, largely predetermined by specific romantic worldview in general. [Volkov, 1998]

At the beginning of the XX century, after some cooling , "eternal prototypical homeland" - Italy again becomes " the dream , the subject of longing , a blessed place, a mysterious and deeply intimate , almost irrationally related Russia ". [Kuchelbecker, 1979]

Thus, for example, for Mikhail Osorgin the " image of Italy " is a sense of a home. "Sometimes, Italy seems to me as my own apartment: «Here is her reception . - Venice ... Here's my library mH Picture Gallery - Florence ... That's my business account for the boring visitors - Milan ... Here Rome - my inner sanctum - a warehouse of values unspeakable..."[Toporov, 1995]

Thus, in the XX century, writers and poets are turning more to the "image" of the Italian cities, rather than to the "image of Italy " as a whole. For example, Pavel Muratov , who in his essays attempts to determine the sense of Rome. "There is no better fate than to die in Rome - he wrote - an entire mile of people are closer to god!" [Muratov, 1911]

The architectural images in the Italian short stories and essays of Osorgin occupy a special place . In the same story «Певец кабачков» we see mutually exclusive motives of the death and forever renewing life. On the one hand, «заглядывая иногда на кладбище у черепичной горы Тестаччо, где под сенью пирамиды Кая Цестия врастает в землю надмогильная плита Шелли...». And on the other hand : «На месте пустырей Prati di Castello вырастали доходные дома...». In this case, mercantile , bourgeois image of the city is not interested to M.Osorgin in this evidence we read «...шаблонный кабачок улицы, слишком центральной и буржуазной». [Osorgin, 1989]

At the beginning of the XX century in the journalism, as well as in the stories of the 30-s, Osorgin created an entirely new way of Italy. The sketches of distinguished contemporary look at the things and kind of language - that simple, then lyrically sophisticated, Italy appears to the reader in all its diversity, with positive and negative - with fascinating colorful personality with a compassionate hospitality to exiles, as well as the problems and conflicts .

According to the researchers, it is Italy that "increased on the ruins of Rome," has played a special role in the spiritual life of Europe. In this regard, at the end of XX - beginning of XXI century explores Russian -Italian cultural relations are trying to re-examine the past to a new stage in history to consider the main stages and aspects of the interaction of two great cultures of Europe, to reveal little-known or not known before the facts creatively rethink the problem interference of Russia and Italy.

So the image of Rome is particularly pronounced in verses of Vyach . Ivanov in the first of his " Римские сонеты ". Sonnet begins welcoming Rome in Latin:

«Вновь древних арок верный пилигрим
В мой поздний час вечерним Ave Roma
Приветствую как свод родного дома
Тебя, скитаний пристань, вечный Puм...» [Ivanov, 1987]

The Latin greeting «Ave, Roma» introduces a semantic layer, which leads to the interior of the mythological stories , meeting , however, as the two ends of the chain with the catastrophic modernity.

The world is compared with a race track, where the state catastrophe is compared to the ancient chariot rigged by the infernal furies of vengeance. Rome, "the queen of ways," watching from afar glow " conflagration ", kindled in the north " on the mountain all bourgeois " [Ivanov, 1987]

If it is logical to continue the comparison, the arrival of Ivanov in Rome and in its flight, and back to the base in the heart of Rome, a new world - the Russian civilization in exile.

The historical reservoir served as the image of Rome in the works of V.Brusov. In 1910-1911 he published in the " Russian idea " his studies of the Roman poets that were the first steps on the path of the writer of artistic exploration of Rome of the IV century. The Bryusov's plans were to make a great book about the Latin writers of the period called «Aurea Roma», which, however, remained unfulfilled. 
In 1902 Valeriy Bryusov traveled to Italy, and the following year published a book of his poems, entitled «Urbi et Orbi», which included his poems created in 1900-1903. Naturally, in the book includes an Italian theme, heard in the very title.

On the characteristic idea of the Acmeism of the unity of the world is based on the concept of Rome and Italy made by Nikolay Gumilev, which is linked to the principle of a single image of the historical period in another one .The italian anthroponomy and place named in the poems of the poet - acmeists, on the one hand, embody a certain era, with its characteristic features, on the other hand, in one way or another relate to the modern epoch of the poet abroad in the XIX-XX centuries, eventually acquiring the status of the eternal, timeless entity.

Italy presented by Gumilev is a sunny Mediterranean country, provided by several of the most representative, typically 'Italian' cities (Rome, Venice, Florence, Genoa, Pisa, Naples, Bologna), the cradle of European civilization, the birthplace of the great poets, painters, sculptors ( Virgil, Dante Tasso, Leonardo, Raphael, Fra Angelico, Canova, etc.). Appeal to the history of ancient Rome, reflections of the laws of development, the rise and fall of the empires Gumilev undertook in order to find the analogies with the present that was typical of the culture of the Silver Age.

The italian images are presented in the works of Anna Akhmaova. For example, in the "Пролог" the italian theme has two distinct dominant - Dante`s theme («Помня место дантовского круга / Словно лавр победного венца», «И «больше нечитавшая») and Roman theme. Rome appears as an epoch in the world history and culture:

«Кажется, я был твоим убийцей

Или ты... Не помню ничего.

Римлянином, скифоом, византийцем

Был свидетель срама твоего». [Akhmatova, 1996]

However, for Akhmatova there was a significant contrast not Catholicism and Orthodoxy, but Paganism and Christianity : " It is said that Rome - this is for her city , where paganism is still waging a war on Christianity ." [Akhmatova, 1996]

The image of Rome has always attracted the attention of Marina Tsvetaeva. For Tsvetaeva the roman image is, first of all , the Ancient Rome, she remembered from her childhood the textbook mythological characters, historical characters and events of antiquity : she compared herself with the Roman wolf («Седеющей волчицы римской / Взгляд, в выкормыше зрящей - Рим!» ; «Это волчицы грусть, / Схожая с громом - / Ромул мой, Ромул!» ), Capitoline geese («Чешские гуси меня ненавидят, капитолийские бы любили»), Gaius Julius Caesar («...Битвы сей / Вы Цезарь» ; «- Вспомни, вспомни, вспомни вождь, - / Мартовские иды/»), Emperor August («Яблоком своим имперским, / Как дитя, играешь, август, / Как ладонью, гладишь сердце / Именем своим имперским» ) and the poet Ovidio to which she dedicated a sonnet , «Как жгучая, отточенная лесть...». [Muratov, 1911]

For Tsvetaeva Rome is a city of love, sung in the " Roman Elegies " of her favorite poet Goethe:

Puм! О тебе говорят: «Ты - мир». Но любовь отнимите,

Мuр без любови - не мир, Рим без любови - не Puм. [Muratov, 1911]

It seems that she continues the motive of Goethe in 1923 in an unfinished poem Tsvetaeva said:

\author{
Речи тайные \\ Розы-к мрамору, \\ Дивно спаяны \\ Roma c Amor'om...[Tsvetaeva, 1989]
}

In the poetic space of Tsvetaeva Rome became the city of love («Дивно спаяны / Roma c Amor'oм»), where even the Capitoline geese would be loved. The name of the town she invariably linked with each other(«Дивно спаяны I Roma c Amor'ом»). She said in the rows that are excluded from the poem «Рано еще не быть...». In "Poem of the End", which also affected her romance with K. Rodzevich, Tsvetaeva comparing her lover with the Roman general, Caesar, and asked him:

«Скажи, что сон!

Что ночь, а за ночью - утро,

Эксnресс и Pum!» [Tsvetaeva, 1989]

As none of the other Russian poets of the "Silver Age" , Osip Mandelštam strongly perceived the connection between the Russian and Italian culture. A good knowledge of the Italian language and literature, the translator of four 
sonnets of Petrarca, Dante and deep knowledge of art, often in his poems Mandelštam displayed a metaphorical images of the Italian cities : Venice, Florence and Rome in particular .

Deepening "the myth of Rome," he repelled by forces linked by many generations , addressed to the liberation of man from his own fate and transformation of ash into the source of continuous renewal. The Eternal City of Mandelštam is a symbolic form of culture. As a poet he understood this character, we can learn from a poem written in 1914:

«Пусть имена цветущих городов

Ласкают слух значительностью бренной.

Не город Рим живет среди веков,

А место человека во вселенной». [Mandelštam, 1990]

In other poems ( 1914 ), so the next the authors drew a parallel between ancient Rome and nature. This we can see in the роет «Природа - тот же Рим...» (1914).

In ancient Rome, nature and culture were united. Therefore, the Roman poet civilization marked by three metaphors that linked three symbolic elements of Roman culture: the circus, forum and colonnade with three elements of nature: blue sky , fields and grove. This unity of nature and culture have helped a person feel global citizen.

Artistically realized continuity of space and time especially noticeable in the largest Italian division cycle Brodsky "Roman Elegies". It is no accident Brodsky summed up his comments: «Что для меня Италия? Прежде всего то, откуда все пошло. Колыбель культуры». [Volkov, 1998]

From the very first verse of "Римские элегии " the poet immerses the reader in the atmosphere of the Eternal City. But we do not find ourselves in the Roman Forum and St. Peter's Square, and the " private residence " lyrical " «Пленное красное дерево частной квартиры в Риме // Под потолком - пыльный хрустальный остров...»[Bodsky, 2002-2007].

One of the main principles of the Italian poems of Brodsky observed the principle of private connections with the general, specific to the eternal : " In Roman " ruins " converge thoughts of death and immortality, eternal and temporal the insignificance of our individual and its involvement in the highest, in short, about the tragedy and the greatness of individual existence "[4] : «Но и птичка из туч вниз не вернется синей // Да и сами мы вряд ли боги в миниатюре // Оттого мы и счастливы, что мы ничтожны...» [Bodsky, 2002-2007].

Italian, especially Roman Brodsky's poems are full of the sunshine: «Я - в Риме, где светит солнце !//Я счастлив в этой колыбели Муз, Права, Граций // Где Назо и Вергилий пели, вещал Гораций» ("Пьяцца Маттеи" 1981) [Bodsky, 2002-2007].

It is not in excess of sunlight, and - in Rome, bestowing a sense of belonging to the poet in the light of ancient culture : «Я был в Риме. Был залит светом так // Как только может мечтать обломок // На сетчатке моей золотой пятак // Хватит на всю длину потемок» [Bodsky, 2002-2007].

In turn, the description of the eternal city conveys to the reader a sense of peace and tranquility «Скорлупа куполов, позвоночники колоколен: Колоннады, раскинувшей члены, покой и нега» [Bodsky, 2002-2007].

Thus, in Russian poetry of the early XXI century we see the development of the Italian images and motives not only due to the Fund of J. Brodsky (M.Ayzenberg, E. Schwartz , T. Kibirov, V.Strochkov, B. Khersonsky), but also immigrant poets, residing in Italy ( Alexandra Petrova ). Italy was the time machine for the Russian poets of the XXI century for its ability to return to basics and principles and still pushes it in its modernity. [Scandura, 2010].

\section{References}

Akhmatova A. Notebooks (Zapisnye knizhki). Moscow-Turin,1996.

Batkin L. Thirtythird letter. (Tridzat tretya bukva). Moscow, 1997.

Brodsky J. [Electronic resource]: [catalog of links] / / Russian Literature and Folklore: Fundam. electron. b-ka. - Moscow, 2002-2007. URL: http://feb-web.ru/feb/feb/sites.htm (22.05.07).

Bryusov V. Favorites (Izbrannoe). Comp. ESavin B., Stavropol, 1996

Volkov S. Dialogues with J.Brodsky. Moscow, 1998.

Vjazemsky V. Verses. Leningrad, 1986.

Garzonio S. Features of vocabulary and imagery of "the Italian text" of Russian poetry // Culture. Moscow, 2001.

Ivanov V. Works in four volumes. V. 1. Brussels, 1987.

Konstantinova S. «ltalian text of the russian literature of XIX-XX s. - Pskov. - 2005.

Kuchelbecker V. Last Colonna // Kuchelbecker V. Adventure. Diary. Articles. Leningrad, 1979.

Mandelštam O. Verses. Translations. Essays. Articles. Tbilissi, «Merani», 1990. 
Muratov P. Image of Italy. V.1. Moscow, 1911.

Osorgin M. Times: autobiographical account. Moscow, 1989.

Scandura C. Rome coincided with the presentation of Rome. Italy in the mirror of the scholars of J.Brodsky. Moscow, «Novoe literaturnoe obozrenie», 2010.

Soviet writers about Italy. Compilation. / Comments byPryadchenko L., Leningrad, «Leninzdat»,1986.

Timenchik R. Rome of Anna Akhmatova: Horror Mortis (1964). Toronto Slavic Quarterly, №21, 2007.

Toporov V. St.Petersburg and its text in the Russian literature // Toporov V. Myth. Ritual. Symbol. Imagine: research in the field of myths and poetics: Favorites. Moscow, 1995.

Toporov V. Italy in St.Petersburg // Italy and Slavonic world. Moscow, 1990.

Tsvetaeva M. Favorites. Moscow, «Prosveschenie», 1989 